\title{
Research on the Training Strategy of Innovative Talents
}

\author{
LI Na \\ Shandong Xiehe University \\ Jinan, 250109, China \\ Lina0704@126.com
}

\begin{abstract}
In order to promote the cultivation of innovative talents, we study from the main body involved in the cultivation of innovative talents, and propose the three party including governments, enterprises and universities to carry out their duties to give full play to its role in cultivating innovative talents. We propose the government should have the appropriate support to cultivate innovative talents by using the game method. The enterprise should strengthen the training, innovate the personnel system to gather all kinds of high-level talents. The colleges should change the concept of personnel training, and innovate the training system and the construction of teaching staff. Finally, it can be concluded that the cultivation of innovative talents can not be separated from three aspects: policy support, education and guidance, and team building.
\end{abstract}

Keywords-innovative talents; develop; training strategy; creative team

\section{INTRODUCTION}

Hu Jintao stressed that human resources were the primary resources when he studied high and new technology industries in Xiamen. He said, we must strengthen capacity building for human resources development, and pay attention to the cultivation of innovative talents especially innovative leading talents, to form a scientific and technological personnel system which is reasonable structure, excellent quality, have both ability and political integrity[1]. Innovative talent can create more innovative efficiency than the general talent, promote the organization member to innovate and succeed, and thus effectively promote the construction of innovative organizations and innovative country.

Innovation is the soul of the country's development and progress, and it is an inexhaustible motive force for the progress of the society. Students' innovative spirit and practical ability are important contents of the quality of personnel training, so to enhance the quality of personnel training, we must strengthen the cultivation of innovative talents. To improve the competitiveness of China's talent, and promote the construction of innovative country, we must cultivate the innovative talents.

The 18th CPC National Congress put forward to implement the strategy of innovation-driven development[2]. Innovation is the driving force for the transformation of the development mode in China, and it is the strategic choice to deal with the new challenge in the new period. Since entering 21st century,

This study is supported by Shandong Provincial Social Science Planning and Management Office (No. 16CGLJ30) and Shandong Xiehe University (No. 2015xh08) the competition is intensifying; its essence is the competition of talents, especially in the civil quality and national innovation ability. Therefore, to occupy a favorable position in the international competition, we must cultivate high-quality innovative talents. Innovative talents are the talents with innovative consciousness, innovative spirit, innovative ability and obtaining innovative results.

\section{The Role of CREative TAlent}

The cultivation of innovative talents plays an important role in the country and the city. David Landers, an economic historian at Harvard University, has studied why the country is rich and poor. Finally, it is concluded that the rich countries are better than the poor countries in the following three aspects. First, the ability to invent and adopt new technology is stronger, which is the ability of people. Secondly, they encourage education and learning, that is the cultivation of people. Thirdly, the system is open and flexible, that is the liberation of people[3]. Therefore, the state development depends on people, especially innovative talents. The specific roles of innovative talents are: first, cultivating innovative talents is helpful to enhance the comprehensive competitiveness of the country and the city, and is also the need to implement the strategy of developing the country through science and education and the strategy of sustainable development. Second, the high level creative talent is the core part of the national innovation system, and it is impossible to obtain a high level of innovation without innovative talents.

\section{Problems IN the Cultivation of InNOvative TAlents}

1. The innovative personnel training mode needs to be changed. The mode of talent training includes family education, school education, amateur education and training, etc. Each education model has its own characteristics. Family education does not pay attention to encourage children, which leads to a lack of confidence, and the education is based on utilitarian, so it causes the child study-weariness. School education is heavy knowledge light practice, valuing experts and neglect of professional talents. Amateur education and training pays more attention to result than process and only focuses on the passing rates and graduation rates, ignoring the essence of amateur education.

2. Talent team construction is insufficient. First, from the quantitative point of view, the absolute amount of our human 
resources is the first in the world, and the R \& D personnel is after the United States, ranked second in the world. But from the comparative quantities, First, from the quantitative point of view, the absolute amount of our human resources is the first in the world, and the R \& D personnel is after the United States, ranked second in the world. But from the comparative quantities, the scientists and technicians are only 200 people in per 10000 personnel, but it is about 4000 people in developed countries. This shows that the proportion of science and technology talents is on the low side in the composition of human resources. Secondly, the innovation ability is not strong, and the citation rate of the thesis is low in our country, only for the average level of the world. Finally, high level talents are relatively scarce. The main reason is that our inputintensity of talent development is not enough, there are many problems in the talent growth environment and we ignore the training of back-up personnel in fund structure and so on.

3. It is difficult to development for scientific innovation team. First, team members and managers are all affected by traditional idea in the development process. Secondly, the performance evaluation mechanism is not perfect. Third, the allocation of resources is unreasonable, often only focus on individuals rather than groups during configuration. Finally, the lack of team management methods, for different types of team should be classified management.

\section{TRAining Strategy OF InNOVATIVE TALENT}

The cultivation of innovative talents requires three parties, as universities, enterprises and governments. The three parties are as table1:

TABLE I. DUTIES OF COLLABORATIVE BODY

\begin{tabular}{|c|c|c|c|}
\hline \multirow{2}{*}{ Duties } & \multicolumn{3}{|c|}{ Collaborative Body } \\
\hline & Universities & Enterprises & Governments \\
\hline Concept & $\begin{array}{l}\text { Change the } \\
\text { concept of talent } \\
\text { cultivation }\end{array}$ & Intensive training & $\begin{array}{l}\text { Security of talent } \\
\text { development }\end{array}$ \\
\hline System & $\begin{array}{l}\text { Innovate training } \\
\text { system }\end{array}$ & $\begin{array}{l}\text { Innovative } \\
\text { personnel system }\end{array}$ & $\begin{array}{l}\text { Improve policy } \\
\text { support }\end{array}$ \\
\hline Talent & $\begin{array}{l}\text { Innovation of } \\
\text { faculty } \\
\text { construction }\end{array}$ & $\begin{array}{l}\text { Gather all kinds of } \\
\text { high-level talents }\end{array}$ & $\begin{array}{l}\text { Public service } \\
\text { system of } \\
\text { innovative } \\
\text { talents }\end{array}$ \\
\hline
\end{tabular}

The main responsibility of the government in cultivating innovative talents is to provide support and guarantee system. The main responsibility of enterprises is to attract and retain innovative talents. The main responsibilities of local colleges and universities in cultivating innovative talents are: education guidance, team building and team development.

1. The potency dimension of government support has a direct impact on the enterprises and local colleges. How can the government support it? We can carry out the game analysis between both sides[4]. In the game, the government makes the decision first, and then the enterprises and universities. The model building process of support dynamics is as follows: Both sides of the game are government and enterprises or colleges. The choice of enterprises or colleges is defined as $\mathrm{Ci}$, and the potency dimension of government support is defined as $\varepsilon$. there into,

\section{$C i=\left\{\begin{array}{c}C i=0 \text { When enterprises ignore innovative talents } \\ C i=1 \text { When enterprises value innovative talents }\end{array}\right.$}

And $\begin{cases}x \quad \text { The percentage of } C i=0 \\ 1-x & \text { The percentage of } C i=1\end{cases}$

The bigger the $\varepsilon$, the greater the government's support.

When the enterprises ignore the innovative talents, the income function of the government and the enterprises are:

$$
\begin{aligned}
& R_{e}\left(C_{i}=0\right)=r_{0} \\
& R_{g}\left(C_{i}=0\right)=m_{0}
\end{aligned}
$$

When the enterprises pay more attention to the innovative talents, the income function of the two are:

$$
\begin{aligned}
& R_{e}\left(C_{i}=1\right)=\varepsilon-r_{0}+r_{1}-C \\
& R_{g}\left(C_{i}=0\right)=m_{1}-\varepsilon+m_{2}
\end{aligned}
$$

$r_{0}$ for enterprises or universities' income that they pay attention to the innovative talent, $r_{1}$ is for enterprises or universities' extraneous earnings, $C$ is for transferred-in cost, $m_{1}$ for government's benefits when enterprises pay attention to the innovative talents, $m_{2}$ for additional revenue.

The average expected revenue of enterprises is defined as $R i$ :

$R_{i}=x R_{e}\left(C_{i}=0\right)+(1-x) R_{e}\left(C_{i}=1\right)=x r_{0}+(1-x)\left(\varepsilon-r_{0}+r_{1}-C\right)$

The duplicate dynamical equation of state is:

$F(x)=d x / d t=x \quad\left(R_{e}\left(C_{i}=0\right)-R_{i}\right\}=x(1-x) \quad\left(2 r_{0}-\left(r_{1}-C\right)-\varepsilon\right)$

Order $F(x)=0, x=0, x-1, \varepsilon^{*}=2 r_{0}-\left(r_{1}-C\right)$

When $\varepsilon^{*}=2 r_{0^{-}}\left(r_{1}-C\right), F(x)$ is equal to 0 ,that is,the government's support began to play a role.

When $\varepsilon>\varepsilon^{*}, F^{\prime}(x=0)<0, F(x=1)>0$, so $x^{*}=0$ is the evolutionarily stable strategy, at this time the government support policies properly, and enterprises have good prospects of gain when they pay attention to the innovative talents.Then the enterprises will select to train and leave on innovative talents. Other enterprises continue to join the ranks by imitation and learning.

When $\varepsilon^{<} \varepsilon^{*}, F^{\prime}(x=1)<0, x^{*}=1$ is evolutionarily stable strategy, this time government support is not enough.

The potency dimension of government's support $\varepsilon \geq 2 r_{0^{-}}\left(r_{1^{-}}\right.$ $C)$ can play its due role, specific measures include: Strengthen the organization and leadership of the government for the cultivation of innovative talents, and fully implement the task, to ensure the implementation of the plan of cultivating innovative talents all right. Guide the establishment of autonomous management system in colleges and universities, establish the main position of university running scholars, and innovate various systems and mechanisms for the cultivation of innovative talents. Change the government's management function to the innovative talents, improve the public service system of innovative talents, promote the government to provide quality public services, speed up and perfect the human resources administrative system and the public service functions, innovative services, improve service means. We will protect the priority input of human capital, and gradually increase the proportion of investment in the development of 
innovative talents. Secondly, improve the science and technology project funds management, the long-term stability of the support of high-level innovative talents and innovative team; develop innovative talent investment evaluation methods and performance management of funds, construction of evaluation system of scientific research institutions in the financial support of the comprehensive performance, to provide protection for the cultivation of innovative talents.

2. The enterprise should construct a mechanism to make the best use of everything. Create a good environment for talents development, form a good situation that policy guidance and career retention. Strengthen the introduction and gathering of innovative talents, innovate the reward system, fully mobilize the initiative and enthusiasm of innovative talents. Reward outstanding contributions of innovative talents, to create a strong atmosphere of scientific and technological innovation and institutional environment. Implement flexible introduction of policies for innovative personnel, extensive recruitment of interdisciplinary knowledge, cross industry experience and broad vision of independent innovation of the leading talent, special talents to give special subsidies and subsidies. Encourage the innovation activities of entrepreneurs, improve the service system that is conducive to the development of entrepreneurship, and play a key role in the independent innovation of enterprises. To develop innovative personnel training plan, the implementation of innovative personnel paid training and academic leave system, improve the training system of skilled personnel to meet the needs of innovative urban construction of innovative talent.

3. Colleges and universities should set up the concept of "student oriented, careful cultivation". The role of teachers is to stimulate students' interest in learning, mobilize their initiative and enthusiasm, and then respect for the development of students' personality and potential. Take the full implementation of quality education as the guiding principle for the cultivation of innovative talents, and regard the renewal of educational ideas as the primary task of cultivating innovative talents in Colleges and universities. For different types of colleges and universities, should be classified to determine the objectives of personnel training: application-oriented colleges and universities to the post or employment oriented, and research universities should focus on cultivating students' innovative thinking ability.

a) Change for innovative personnel training mode.

Redetermine the training objectives of talents. Different types of colleges should be classified to determine the training objectives. The applied university should take the position or the employment as the guidance, and the research university should pay attention to cultivating students' innovative thinking ability. Knowledge is of value in itself, so when the university provides students with college education, it should not only consider his first job, but care more about his subsequent development. Construct scientific personnel training pattern. First of all, the curriculum system should be added entrepreneurial education courses based on the basic course and professional courses, because entrepreneurship itself is a kind of innovation[5]. Second, we should pay special attention to practical teaching, through the establishment of a new system of practical teaching which is multi-level, modular, combination of ability training and skill training, combination of scientific research and experiment teaching, and including course experiment, practice training, scientific research, and personalized training etc to cultivate students' practice ability. Third, personnel training credit system should be carried out, it can not only improve the teachers' sense of competition, teaching ability and enthusiasm, but also stimulate students' enthusiasm for learning and innovative spirit.

\section{b) Strengthening the construction of talent team.}

Innovate the system of talent training in Colleges and universities. Institutional innovation is the organizational guarantee for the cultivation of innovative talents. the innovation of the college system include: the first is the innovation of educational management system, through the improvement and innovation of school running mechanism, promote the sustainable development of the school, which provides a hardware foundation for the cultivation of innovative talents; the second is innovation education system, and actively introduce outstanding educational resources at home and abroad, strengthen the cooperation between universities and enterprises, cultivate students' practical ability in practice, to provide innovative talents for enterprises. With the regional economic and social demand as the guidance, to explore the characteristics of the way to school, take the connotation of development and expansion of the expansion of the development path; the third is the innovation incentive and evaluation system, according to the different interests and talents of students, develop different forms of assessment methods, examination content, standard for evaluation, the comprehensive it differs from man to man. Outstanding students, give performance incentives at the same time, issued its certificate of innovation, in order to stimulate students' innovation consciousness, provide the conditions for the cultivation of innovative talents.

Innovate the construction of college teachers. First of all, the introduction of talents with practical experience from enterprises and scientific research institutes, which integrate the existing teachers; the second is to encourage and create opportunities for existing teachers engaged in practical activities to the enterprise deeply, to improve teachers' practical ability, to pave the way for practical innovation, teachers' participation in practice can take stage practice or attachment; in addition, the basic standard to develop college teachers' innovative quality, the scientific research and practice into teaching assessment measures to improve teachers' innovative quality. Allow talent's free move. To fully tap the creative potential of human, first of all, talent can flow freely to play to your strengths and avoid weaknesses. Through the free flow, people can contact with different ways of thinking and professional personnel, also they can be mutual inspiration and collisions to produce a creative spark. Create an academic atmosphere of democracy. Creative thinking is a complicated process, so to judge various creative thinking right or wrong, we only can discuss with academic democratic approach that is "let a hundred flowers blossom and a hundred schools of thought contend", and carry out the principle that everyone is equal before the truth and the academic. Administrative means can not be taken to the 
viewpoint of academic innovation, because this will suppress creative thinking and creative behavior.

c) Promoting the development of science and technology innovation team.

The management system of scientific and technical personnel should be improved, to encourage the transformation of innovative achievements. Scientific and technical personnel need compete for a post, and they will paid by post, by task and by performance. Scientific research institutions, colleges and universities should pay attention to the cultivation and use of innovative leaders, and strive to create a good environment and conditions for the technology and management personnel who have courage to implement disruptive innovation[6]. We should correctly evaluate the innovation achievement and reward. According to the different characteristics of various scientific and technological activities, different evaluation criteria and methods should be used and the number of awards should be compressed, to improve the intensity of incentives. Implement policies supporting fiscal and taxation. We should provide financial support for the transformation of new and high-tech achievements, and implement tax policies support for high-tech products. The revenue of technical transfer, technical development and related technical consulting, technical services shall be exempted from business tax. To promote the development of science and technology innovation team by increasing the input of innovation activities. Strengthen the administration and protection of intellectual property rights. For the Innovation achievement, attention should be paid to the use of intellectual property system to protect their legitimate rights and interests. For intellectual property rights of the inventor, designer, author and the main perpetrators, remuneration and equity returns that is corresponding to the actual contribution should be given. We should vigorously strengthen the legal publicity and personnel training of intellectual property rights, to guide enterprises, scientific research institutions and institutions of higher education to establish and improve the management system of intellectual property rights.

\section{CONCLUSION}

In short, the cultivation of innovative talents can not be separated from the guidance and training of education, the development of innovative team and the construction of innovative talents. With the Party Central Committee paying attention increasingly to innovative talents, the corresponding construction being strengthening, and the improving of the problem, our innovative talents training will achieve greater achievements.

\section{REFERENCES}

[1] Hu Jin-tao, “Visits to Xiamen”, people's daily,2006(In Chinese)

[2] Hu Jin-tao, "Unswervingly follow the road of socialism with Chinese characteristics and strive to build a moderately prosperous society in an all-round way”, The 18th Communist Party of China National Congress, Beijing,2012 (In Chinese)

[3] David S.Landes,'The wealth and poverty of nations:why some are rich and some so poor”, Xinhua Publishing House,2007

[4] Tom Siegfried,A beautiful math:John Nash,game theory,and the modern quest for a code of nature, Chemical Industry Publishing House,2011

[5] Liang Xingmin,Study on the establishment and evaluation of the curriculum system of personnel training in management discipline ,Harbin Engineering University, 2013(In Chinese)

[6] $\mathrm{Li} \mathrm{Na}, \mathrm{Li}$ Ruixue,Wang Chunmei, Research on the promotion of enterprise competitiveness based on disruptive innovation ,Value Engineering,2012,p.127(In Chinese) 